\title{
UNION RETIREMENT AND WELFARE PLANS: EMPLOYER CONTRIBUTIONS AS "WAGES" UNDER SECTION 64a(2) OF THE BANKRUPTCY ACT*
}

THe most undesirable feature of union retirement and welfare funds is the employee's uncertainty of ever receiving any benefits from his employer's contributions to the fund. ${ }^{1}$ Often the worker's expectations are thwarted through his own choice when he voluntarily ceases his employment before being entitled to draw from the fund. Although a few plans permit the employee to recover his own contributions in this event, ${ }^{2}$ most plans deny any recovery regardless of the reason for severance; none permit the worker to recover his employer's contributions. 3 Apart from a voluntary withdrawal, several factors outside

:In re Sleep Products, Inc., 141 F. Supp. 463 (S.D.N.Y. 1956); In re Schmidt, 33 L.R.R.M. 2283 (S.D. Cal. 1953).

1. Critics of private pension plans have long deplored both the fact that the employee must remain with a single firm to realize retirement benefits and the possibility of revocation by the union or the employer in a contract subsequent to the creation of the fund. See Dearing, Industrial Pensions 98-100 (1954) ; Comment, 59 Yale L.J. 678, 707-09 (1950). Some commentators have urged the abandonment of private plans in favor of a federally sponsored program akin to social security. Id. at 712-14. In some industries poolcd plans offer some assurance of permanency by guarding against frequent shifts of employment, but even these plans are confined to specific geographic areas and specific employers. Benefits are, therefore, still contingent. Dearrng, op. cit. sitpra at 100-03. See also note 3 infra.

2. See Gould v. United Traction Co., 282 App. Div. 812, 122 N.Y.S.2d 662 (3d Dep't 1953) (plan allowing employee to recover own contributions upon voluntary severance of employment does not permit recovery when employee remains on job and merely withdraws from plan). In addition, a few plans permit discharged employees to recover their own contributions. See Doyle v. French Tel. Cable Co., 244 App. Div. 586, 280 N.Y. Supp. 281 (1st Dep't 1935) (plan, in terms, allowed discharged employees to recover own contributions, but court held French statute providing that upon discharge employee contributions are turned over to national pension fund to be controlling) ; Cowles v. Morris \& Co., 330 Ill. 11, 161 N.E. 150 (1928) (company discharged all its employees because of business failure; employees' contributions held properly returned to them even though this so reduced the fund that it was impossible to continue payments to pensioners who had already qualified).

3. Although the nature of employees' rights under the relatively new union welfare plans has not yet been fully determined by the courts, it appears certain that many of the traditional concepts that have governed private plans between employers and employees will be carried over to union plans Since each case rests upon the terms of the plan itself and controlling statutes, the courts have developed few rules for private plans. The employer's promise of a pension has been treated alternatively as: a mere gratuity conferring no rights upon the would-be pensioner, Dolan v. Heller Bros. Co., 30 N.J. Super. 440, 104 A.2d 860 (Ch. 1954); an offer for a unilateral contract enforceable when the employee has fully complied with the conditions of the offer, Schofield v. Zion's Co-op. Mercantile Institution, 85 Utah 281, 39 P.2d 342 (1934); or a declaration of trust, Annot., 42 A.L.R.2d 461, 471-72 (1955) (citing Lewis v. Jackson \& Squire, Inc., 86 F. Supp. 354 (W.D. Ark. 1949), which rejected the trust theory because no res in existence at time of 
the employee's control may cut off his prospective right to all benefits from the fund. The employee may be discharged, ${ }^{4}$ those in charge of the fund may by mismanagement or corruption dissipate the proceeds, ${ }^{5}$ or the union and the employer may agree to revoke the plan. ${ }^{6}$ In addition, the Bankruptcy

declaration of trust). Under the unilateral contract rationale, the rule that part performance by the offeree binds the employer to keep his offer open, e.g., REsTATEMIENT, ConTRACTS $\$ 45$ (1932), may give some protection to the discharged employee but is of no advantage to the worker who leaves voluntarily. Usually, however, discharge for cause leaves the employee without remedy. But a discharge obviously calculated to evade payment of the pension will not deprive the worker of his pension. Wilson v. Rudolph Wurlitzer Co., 48 Ohio App. 450, 194 N.E. 441 (1934). Under any view, the employee has no vested rights in the pension fund until he has satisfied the announced conditions of eligibility. And this rule can not even be changed by statute. Standard Oil Co. v. Porterie, $12 \mathrm{~F}$. Supp. 100 (E.D. La. 1935) (statute providing for a right to payment after serving onefourth of the required time was unconstitutional invasion of employer's property rights); See Note, 20 NeB. L. REv. 53, 55-57 (1941).

In a bargained-for union welfare fund, the employer's promise must realistically be treated as a contract, since the plan is obligatory on the employer. See, e.g., Vallejo v. American R.R. Co., 188 F.2d 513 (1st Cir. 1951). Before the employee has satisfied the conditions of eligibility as announced by the trustees of the fund, most plans deny him any option to receive the employer's contributions in cash, either upon termination of the plan, through severance of employment or otherwise. And it appears equally unlikely that the employee has a severable right to his own contributions when he withdraws from the plan, since he has received consideration in the form of insurance protection during his employment, and since he surrenders his rights to the fund under the terms of most fund agreements. Even after he has met the conditions of eligibility prescribed by the fund, the employee's only remedy against the trustees for refusing to pay a pension is to show that they have unreasonably discriminated against him or that they have abused the "full authority" vested in them by the fund agreement. See, e.g., Geron v. Kennedy, $381 \mathrm{~Pa}$. 97, 112 A.2d 181 (1955). But see Forrish v. Kennedy, $377 \mathrm{~Pa} .370,105$ A.2d 67 (1954) (where trustees have unlimited discretion, court will not control it but will insure that it be exercised within bounds of "reasonable judgment").

4. See note 3 supra.

5. See, generally, Perkins, Protection of Labor Union Funds by Members Representative Suits-Massachusetts Practice, 27 B.U.L. REv. 1 (1947) (discussion of remedies available to members for misappropriation of funds by union officers); United States v. Ryan, 350 U.S. 299, 304-05 (1956) (discussion of congressional efforts to cope with the "welfare fund problem"); Matter of Brassel, 135 F. Supp. 827, 830 (N.D.N.Y. 1955) (no hint of mismanagement, but court notes that contributions may be entirely exhausted by the expense of administration). For provisions of the Taft-Hartley Act, 61 STAT. 136 (1947), 29 U.S.C. $\$ \$ 141-68$ (1952), relating to the security of welfare funds, see note 51 infra. The purpose of such legislation

“. . . is that the welfare fund shall be a perfectly definite fund, that its purpose shall be stated so that each employee can know what he is entitled to, can go to court and enforce his rights in the fund, and that it shall not be, therefore, in the sole discretion of the union or the union leaders and usable for any purpose which they think is to the advantage of the union or the employee. ..."

Statement by Senator Taft, 93 Cong. REc. 4746-47 (1947), quoted in Local 333, United Marine Div., AFL v. Essex Transp. Co., 216 F.2d 410, 412 (3d Cir. 1954).

6. See Comment, 59 YaLE L.J. 678, 707-08 (1950). And the employee has no guarantee that the union and the employer will authorize continuance of the plan in subsequent 
Act, as recently interpreted by the courts, may frustrate the employee's expectations. Although section $64 a(2)$ explicitly grants a priority in bankruptcy distributions to unpaid wages, ${ }^{7}$ it is unclear whether the priority will extend to the bankrupt employer's unpaid contributions to retirement and welfare funds.

In two recent cases involving similar facts, ${ }^{8}$ In re Sleep Products, Inc. ${ }^{9}$ and In re Schmidt, ${ }^{10}$ federal district courts arrived at opposite results when trustees of the funds claimed a wage priority for unpaid employer contributions. In both cases unions had negotiated collective bargaining contracts, under which the employers promised to make payments into a welfare fund as long as the collective agreements remained in force. ${ }^{11}$ Eligibility for pension benefits depended on working for an employer covered by the agreements for a specified minimum number of years prior to the date of retirement. ${ }^{12}$ The agreements expressly provided that "under no circumstances ... shall the title to said

collective agreements. The Internal Revenue Code offers some inducement to the parties not to revoke. See note 51 infra.

As to the disposition of the funds already collected after a plan ceases, see George v. Haber, 343 Mich. 218, 72 N.W.2d 121 (1955) (employer moved plant; participating employees not entitled to divide up welfare fund); del Veccio v. Hood, 4 N.J. Super. 254, 66 A.2d 73S (App. Div. 1949) (contract establishing noncontributory plan expired; $\$ 25,000$ in fund can be used for benefit of employees subsequently hired).

7. 30 StAT. 563 (1898), as amended, 11 U.S.C. $\$ 104$ (1952) provides:

"(a) The debts to have priority, in advance of the payment of dividends to creditors, and to be paid in full out of bankrupt estates, and the order of payment, shall be ... (2) wages not to exceed $\$ 600$ to each claimant, which have been earned within three months before the date of the commencement of the proceeding, due to workmen, servants, clerks, or traveling or city salesmen on salary or commission basis, whole or part time, whether or not selling exclusively for the bankrupt. ..."

8. Schmidt extended the wage priority to both employer and employee contributions. In Sleep employee contributions were not considered, but this, of course, does not help explain the different results. Employee contributions -will not be considered further in this Note. For the other factual distinction, the differing methods of computing the employers' contributions (which Sleep deemed significant), see note 14 infra.

9. 141 F. Supp. 463 (S.D.N.Y. 1956).

10. 33 L.R.R.M. 2283 (S.D. Cal. 1953).

11. Collective Agreement of Aug. 1952 in Sleep: "Thirty-Second: The Employer hereby agrees, as long as this agreement remains in effect, to pay monthly. ..." Although the Labor Agreement in Schmidt did not expressly so limit the employer's obligation to contribute to the life of the contract, such is implied since the provisions creating the fund are among the other provisions relating to employees' compensation under the agreement.

12. $141 \mathrm{~F}$. Supp. at 465 . In addition to time worked, many plans condition the receipt of benefits from the fund on union membership. See Dearing, Industrial Pensrons 102 (1954). But the legality under the Labor Management Relations Act of this basis of eligibility is doubtful. See Penello v. International Union, United Mine Workers, ss F. Supp. 935, 939 (D.D.C. 1950) (insistence by union that any collective contract containing welfare fund provisions be administered to provide benefits exclusively for union members is unfair labor practice as a refusal to bargain in good faith and coercion of employer discrimination). 
funds remain in the employee"; nor did he retain an option to receive any part of the contributions in cash, either upon termination of the plan or the worker's withdrawal from the fund, including a withdrawal forced by loss of his job. ${ }^{13}$ Both employers went into bankruptcy before bringing their payments into the fund up to date.

The Sleep court denied priority to the unpaid contributions, reasoning that they were not "wages . . . earned within three months ... due to workmen," within the meaning of section $64 \mathrm{a}(2) .{ }^{14}$ Since the collective bargaining agreement specified that the amounts were to be paid directly to the trustees of the fund and that, in the event of nonpayment, the union could sue, ${ }^{15}$ the court

13. Agreement and Declaration of Trust, March 1952, by Trustees of Local 140 Pension Fund, United Furniture Workers, CIO, para. 4, quoted in Slecp, 141 F. Supp. at 465-66. See also the collective bargaining agreement of May 1952, between Lacal 2, Operative Plasterers and Cement Finishers, AFL, and Contracting Plasterers Ass'n, IV, para. e-2 (Schmidt).

14. See note 7 supra. The single factual distinction between the two cases-in Slecp the employer's contribution was measured on the basis of the gross monthly payrolls of all employees participating while in Schmidt the employer deducted six and one quarter cents per hour from each worker's wage and then contributed a like amount-should not account for such conflicting results. Yet the method of computation in Sleep led that court to conclude that the employer's contributions were not "earned" by any particular employee and so not entitled to the wage priority. $141 \mathrm{~F}$. Supp. at 467 . The argument, however, overlooks that the contributions are collectively "earned" and that $\$ 64 a(2)$ contains no stricture of collective earnings. Furthermore, assuming that the contributions are "wages," case law suggests that the method of computing the "wages" is of no relevance in the determination of priority. In re Gurewitz, 121 Fed. 982, 983 (2d Cir. 1903). Moreover, these payments are "earned" as much as the additional compensation paid under an "escalator clause" to an employee as the result of an increase in the cost of living. Again, they are "earned" more than an NLRB back pay award for improper discharge or vacation pay "earned" prior to the three month period, which have been treated the same as any wage claim. NLRB v. Killoren, 122 F.2d 609, 614 (8th Cir.), cert. denied, 314 U.S. 696 (1941) (back pay award "constructively earned") ; Nathanson v. NLRB, 344 U.S. 25 (1952) (back pay award would be treated same as wage claim if actually "earned" within three month period); In re Kinney Aluminum Co., 78 F. Supp. 565 (S.D. Cal. 1948) (vacation pay entitled to priority although the services giving rise to the claim were performed prior to three month period). Contra, Kavanas v. Mead, 171 F.2d 195 (4th Cir. 1948) (not sufficient that only legal right to vacation pay accrued within three month period).

15. $141 \mathrm{~F}$. Supp. at 466 . The collective agreement with Local 140 states:

"THIRTY-THIRD:... In the event that the employer should fail to pay on or about the 10th day of each month all monies due to the Local 140 Security Fund, then, in such event, the Union shall be entitled to liquidated damages in the sum of six $(6 \%)$ percent of the amount due in addition thereto."

This provision does not specifically say that only the union may sue; it could imply that the employee might sue for unliquidated damages. However, the fact that a collective contract clearly states that it is enforceable only by the union has been held to deny the employee any standing to sue for the employer's breach. Whyte v. F.D.S. Corp., 10 L.R.R.M. 534 (N.Y. Sup. Ct. 1942). Cf. International Harvester Co. and Local 104, United Farm Equip. Workers, CIO, 9 Lab. Arb. 894 (1947) (presence or absence of a liquidated damages clause does not control determination of appropriate remedy). 
concluded that the employee could not sue the employer to enforce his promise; hence, the contributions were said to be "due to" the fund, not to workmen. ${ }^{16}$ Moreover, the contributions were held to be outside the scope of the term "wages" for two reasons. They are not accorded the same tax treatment as other types of compensation to employees, and the legislative intent underlying section $64 \mathrm{a}$ (2) would not, the Sleep court felt, have sanctioned protection to welfare fund benefits which are "indefinite, contingent and prospective."17

The earlier decision to the contrary in Schmidt did not turn upon the interpretation and application of these terms of section $64 \mathrm{a}(2)$. The court there apparently assumed that the requirements of the statute were met; it considered only the objection of the trustee in bankruptcy that, if the contributions were "due to" the employees, the trustees of the fund were not the proper claimants. The court rejected this contention by construing the collective largaining agreement to be an equitable assignment from the employees to the trustees. ${ }^{18}$ But Schmidt's analysis never answers the basic question raised in Sleep-whether, absent or prior to an assignment, the contributions were ever "due to" the employees for the purposes of the Bankruptcy Act.

16. In interpreting the phrase "due to workmen," the court seemed to suggest that $\S$ $64 \mathrm{a}(2)$ required that the "wages" earned by workmen be directly payable only to them. The language of the act does permit this interpretation, and it has been adopted in one previous case, Matter of Brassel, 135 F. Supp. 827 (N.D.N.Y. 1955). But, with this one exception, the courts have ascribed a different meaning to the statute. Section 64a (2)'s wage priority has long survived an assignment by the employee even though the "wages" are then "due to," and the priority benefits, the assignee. See note 18 infra; see also Kavanas v. Mead, 171 F.2d 195, 198 (4th Cir. 1948) (equating "due" with "owing"). Moreover, the entire phrase "due to workmen, servants, clerks or . . . salesmen . . . ;" may fairly be construed as limiting only the types of employees whose wages may receive the priority. Had the drafters intended to give the word "due" any independent meaning which could limit the type of wages eligible for the priority, they probably would have repeated the syntax used in the preceding limitation ("wages ... which have been earned"). Thus the clause would read "wages ... which have been earned ... and which are due to workmen...."

And even if the Slecp and Brassel interpretation is correct, the contributions are "due" to the employee in the sense that he has a legally enforceable right to compel payment. See note 35 infra and accompanying text. Furthermore, apart from the money value of these benefits when received, the expectation of receiving them is valuable to the worker. Since the term "wages" is liberally interpreted for the benefit of the employee, ste nute 42 infra and accompanying text, it may include this expectation. These "wages," then, are immediately "due to" the employee, for the employer has a present contractual duty to perform the act that creates the expectation, contributing periodically to the fund. And employees reduce their wage demands to obtain this present expectation. See note t5 infra and accompanying text. But Slcep, following Brassel, supra, refuses to recognize that "wages" may include such intangible benefits.

17. 141 F. Supp. at 467.

18. 33 L.R.R.M. at 2284. The assignee of a wage claim is given the same priority as the assignor would have. See Shropshire Woodliff \& Co. v. Bush, 204 U.S. 186 (1907); In re Ross, 117 F. Supp. 346, 347 (N.D. Cal. 1953) ; In re Stultz Bros., 226 Fed. 989, 990 (S.D.N.Y. 1915); cf. Freeman Furniture Factories v. Bowlds, 136 F.2d 136, 140 (6th Cir. 1943). 
Furthermore, the Schmidt court's assignment reasoning brings a new and unnecessary problem to an area already marked by notable distortions of traditional contract theory. ${ }^{19}$ The court stated that the employee had assigned all his rights in and to the fund. ${ }^{20}$ But since the sole issue raised was the fund trustees' standing to ste, only an assignment of the employee's right to collect the contributions was essential to the decision. ${ }^{21}$ The court's suggestion that the employees had assigned all their rights in the fund would deny them any rights against the trustees in the event the latter took no action to collect contributions promised by the bankrupt or misused funds already collected.22

An analysis of union welfare plans reveals, however, that employees do have the legally enforceable rights which the Schmidt rationale would deny and which the Sleep court would require under its interpretation of the "due to workmen" clause. Courts have long tried to give the individual standing to sue by fitting union agreements into traditional legal categories. They have permitted the individual employee to sue as a third party beneficiary, ${ }^{23}$ as

19. See notes 27 and 28 infra. The following illustrates some of the conceptual difficulties of the assignment theory. Two years after the fund has been established, the trustees negotiate a supplemental agreement with the employer to increase his contribution from six cents per hour per employee to seven cents. Questions which may then arise include: whether there is another equitable assignment of the extra penny; whether absent a formal ratification of the increase by the union members, a court may infer an intent of the employee to assign; whether a dissenting minority still has an intent to assign. In the absence of a written assignment for value an intent to assign is essential. 4 CORDIN, CONTRACTS $\$ 879$ (1951).

20. "The assignors, the employees, did not retain any control over the fund, any authority to collect, or any power of revocation. ... An equitable assignment requires that there should be a complete and present right to the fund conferred on the assignee. ..."

33 L.R.R.M. at 2285.

21. That a limited assignment of the claim for the purposes of collection is possible, see 4 Corbin, Contracts $\$ 882$ (1951). Apparently there was no evidence in Schmidt outside of the bargaining contract which would point to such an assignment. Had the employees made a formal assignment, it would have been unnecessary to construe an equitable assignment from the provisions of the contract.

In Slecp, where the agreement creating the fund recited the employee's lack of an assignable interest in the fund, it would have to be argued that the employee has an interest in yet unpaid contributions and may assign the right to collect contributions not yet part of the fund.

22. See note 35 infra and accompanying text. In addition to the theory suggested in note 21 supra, the trustees could have been granted standing to sue on another ground. There are analogous situations in which persons other than the wage earner may present a claim. In NLRB v. Killoren, 122 F.2d 609 (8th Cir.), cert. denied, 314 U.S. 696 (1941), the court held that the Board, in seeking to collect a back pay award from a bankrupt estate, was a "creditor" within the meaning of $\$ 1(11)$ of the Bankruptcy Act and, as such, was entitled to claim the employee's wage priority. The court found the Board's status to be "in the nature of a plenary trusteeship." Id. at 612. See Nathanson v. NLRB, 344 U.S. 25 (1952) (although Board's standing to sue as claimant affirmed, back pay award not entitled to wage priority).

23. In re Norwalk Tire \& Rubber Co., 100 F. Supp. 706 (D. Conn. 1951); Ryan v. 
the principal in an agency relationship, ${ }^{24}$ or as one of the parties to a contract of hire the terms of which incorporate, under a usage theory, the terms of the collective agreement. ${ }^{25}$ By allowing employees to enforce collective bargaining contracts, the agency and usage concepts were useful as common law devices to uphold the otherwise unenforceable terms of collective agreements. When statutes finally made these contracts directly enforceable, ${ }^{26}$ the agency and usage doctrines, which had always encountered theoretical difficulties, became unnecessary. ${ }^{27}$ Although the third party beneficiary doctrine also raises difficulties, ${ }^{28}$ the courts, nevertheless, still entertain suits brought by the employee in

Kyan, 156 Kan. 348, 133 P.2d 119 (1943) ; Gulla v. Barton, 164 App. Div. 293, 149 N.Y. Supp. 952 (3d Dep't 1924) ; Helt v. Britten-Fenton Co., 180 Misc. 1077, 44 N.Y.S.2d 58 (Sup. Ct. 1943) ; J. I. Case Co. v. NLRB, 321 U.S. 332 (1944) (dictum). Even an employee not a union member may have rights as a third party beneficiary under the collective contract. See, e.g., Leahy v. Smith, 290 P.2d 679 (Cal. 1955).

24. Christiansen v. Local 680, Milk Drivers and Dairy Employees, 126 N.J. Eq. 508, 10 A.2d 168 (Ch. 1940) (union officers are agents in negotiating collective contracts but causes of action arising thereunder belong to employees); Mueller v. Chicago \& N. Ry., 194 Minn. 83, S5, 259 N.W. 798, 799 (1935) ; West v. Baltimore \& O.R.R., 103 W. Va. 417,137 S.E. 654 (1927) (to have rights as principal, employee must have ratified collective agreement).

25. Yazoo \& M.V.R.R. v. Webb, 64 F.2d 902 (5th Cir. 1933); United States Daily Publishing Corp. v. Nichols, 32 F.2d 834 (D.C. Cir. 1929) ; Hudson v. Cincinnati Ry., 152 Ky. 711, 154 S.W. 47 (1913). Cf. Aulich v. Craigmyle, 248 Ky. 678, 59 S.W.2d 560 (1933).

26. Among the reasons advanced by courts of a bygone day for declaring collective bargaining agreements unenforceable, the most significant were: the union as an unincorporated association lacked standing to sue or be sued, e.g., Hallman v. Wood, Wire and Metal Lathers Int'l Union, 219 N.C. 798, 15 S.E.2d 361 (1941) ; no consideration moved from the union; a contract of personal services could not be specifically enforced, and, conversely, the union could not enforce since there was no mutuality of remedy. See Witmer, Trade Union Liability, 51 YALE L.J. 40 (1941). Beginning with Schlesinger v. Quinto, 201 App. Div. 487, 194 N.Y. Supp. 401 (1st Dep't 1922), and culminating with $\S 301$ of the Taft-Hartley Act, enforceability has become well-established.

27. The chief difficulty with the usage theory is that to call a collective contract arrived at after prolonged deliberation, subject to change by mutual consent, and only existing for a specified period a "usage" is to stretch that concept to the point where its application has no meaning except in terrns of legal consequences. In addition, the usage theory makes necessary in each case an inquiry into whether the employee suing contracted with reference to the usage. The employee's knowledge of the terms of the collective agreement when entering into the contract of hire thus becomes a question of fact.

Similarly, the agency theory has disadvantages. The employee may not have been a union member when the collective agreement was made; he may have been a member Lut voted against giving the union the authority to negotiate the provision he is suing on; he may have to point to some evidence that the union acted as his agent. Furthermore, this rationale deprives the union of any right to enforce the contract.

For discussion of these theories, see Mathews, Labor ReLatrons aNd THE Law 305-07 (1953); 1 Teller, Labor Disputes and Collective Bargaintag $\$ \$ 159$, 166-6\$ (1940); Witmer, Collectiz' Labor Agreements in the Courts, 48 YaLe L.J. 195 (1938).

2S. The employee who is a member of the union is a part of a party to the contract, and as such could be deemed an obligor. But ordinarily a third party beneficiary cannot be a party owing any duty of performance under the contract. See 4 Conbin, Contracts 
that capacity. ${ }^{29}$ In the welfare fund context, however, this doctrine may be unusable. For a third party beneficiary cannot sue when the contract indicates that the parties intended him to have no such right. ${ }^{30}$ The collective contract in Sleep, denying the employee any right or title to the fund and providing for a suit by the union in the event of the employer's nonpayment, may indicate such an intent. But since the Sleep contract did not, in so many terms, deny the employee the right to sue, the contract can still be construed to permit the employee to sue in this situation.

The most recent approach, moreover, has been to put to one side these familiar concepts and to treat a union agreement as a contract sui generis. ${ }^{31}$ According to this view, standing to sue should "depend upon the character or rights the contract was intended to create."32 A federal court, relying on

$\$ \$ 778-79$ (1951) (party furnishing consideration usually cannot be a third party beneficiary) ; 1 TELler, op. cit. supra note 27, at $\$ 168$; Witmer, supra note 27 , at 228, 236.

29. See note 23 supra.

30. 4 Corbin, Contracts $\$ 777$ (1951).

31. Cox, Rights under a Labor Agreement, 69 HARv. L. REv. $601,618-19$ (1956); Witmer, Collective Labor Agreements in the Courts, 48 Y ALE L.J. 195, 238 (1938).

32. Cox, supra note 31 , at 645 . The author argues that the parties to a collective contract should be able to stipulate in the agreement who has enforceable rights in the event of breach. But where the employee's personal stake is significant, as with most fringe benefits, and the contract has neither provided for grievance or arbitration procedures nor otherwise indicated an intent that the union handle the dispute, the courts should presume that the parties intended to leave to the individual employee the right to sue directly on the contract. $I d$. at $652-56$.

Normative considerations aside, the case law suggests a different approach. In state courts, the third party beneficiary theory still carries great weight. See note 23 sitpra and accompanying text. Nor does it appear to stretch the concept unduly to allow the employee to sue the bankrupt for nonpayment of contributions. Union opposition to the individual action does not affect adversely the application of third party beneficiary doctrine. See, e.g., Rolandez v. Star Liquor Dealers, Inc., 3 L.R.R.M. 771 (N.Y. Sup. Ct. 1938) (union may not waive rights inserted in collective bargaining agreement for employee's benefit without his consent after he has been recognized by employer as a beneficiary).

In the federal courts, however, the individual employee has no standing to sue the company for nonperformance unless he establishes diversity jurisdiction. See, c.g., Schatte v. Theatrical Stage Employees, 84 F. Supp. 669 (S.D. Cal. 1949), aff'd, 182 F.2d 158 (9th Cir.), cert. denied, 340 U.S. 827 (1950) ( $\$ 301$ of Taft-Hartley, 61 STar. 156 (1947), 29 U.S.C. $\$ 185$ (1952), does not permit individual employees to enforce collective contracts in federal courts). Under Westinghouse Salaried Employees v. Westinghouse Elec. Corp., 348 U.S. 437 (1955), however, the union cannot sue in the federal courts to enforce the employees' personal rights under the union contract. The employer's promise to make payments to a health and welfare fund creates personal rights. International Ladies' Garment Workers' Union, AFL v. Jay-Ann Co., 228 F.2d 632 (5th Cir. 1956) (relying on Westinghouse's holding that union cannot enforce in federal courts the personal rights of employees to receive compensation). See Mendelsohn, Enforccability of Arbitration Agreements under Taft-Hartley Section 301, 66 YALE L.J. 167, 194-98 (1956). But cf. Local 333, United Marine Div., AFL v. Essex Transp. Co., 216 F.2d 410 (3d Cir. 1954) (union recovers in suit to compel employer to make payments to pension fund). 
the reasoning of the Westinghouse case, ${ }^{33}$ has held that the employer's promise to contribute creates personal rights which the union may not enforce. ${ }^{34}$ Even assuming that the contract expressly denied the individual standing to sue the employer directly, it may nevertheless create rights in the employee. He is the beneficiary of fiduciary obligations which the trustees of the fund owe and could sue the trustees in equity to compel them to enforce the employer's promise. ${ }^{35}$ The worker need only show that he has exhausted his other remedies before seeking judicial intervention. ${ }^{36}$ Whether the employee has the right to sue the employer for nonpayment as a third party beneficiary or whether the employee can sue the trustees for breach of fiduciary duties created by the bargaining agreement, the unpaid contributions are, in a very real sense, "due to workmen."

In reasoning that such contributions were not "wages" under section $64 a$ (2), the Sleep court signalled the fact that employer contributions are not treated as wages for purposes of withholding both income ${ }^{37}$ and social securi-

33. Westinghouse Salaried Employees v. Westinghouse Elec. Corp., 348 U.S. 437 (1955).

34. International Ladies' Garment Workers' Union, AFL v. Jay-Ann Co., 228 F.2d 632 (5th Cir. 1956). See note 32 supra.

35. Cox, supra note 31 , at 645 . The author analogizes the employee's suit against the union with the rule permitting the beneficiary of a trust to maintain a suit in equity against the trustee and the third person when the trustee improperly refuses to bring an action against the third person. See 2 Restatement, Trusts $\$ 282(2)$ (1935); cf. id. $\$ 322$. In the welfare fund situation, the analogy to a trust fails if the employee is not considered the beneficiary of the fund because of the indefinite receipt of benefits and the absence of his right or title to what would be comparable to the trust res. But see Local 333, United Marine Div., AFL v. Essex Transp. Co., 216 F.2d 410 (3d Cir. 1954) ("They are trustees of a fund and have fiduciary duties in connection therewith as do any other trustees.").

Even without the trust analogy, the employee's suit against the trustees of the fund can be likened to suits by union members against the officers for diverting funds acquired for sick or death benefits from such purposes. See, e.g., Suffridge v. O'Grady, 84 N.Y.S. $2 d 211$ (Sup. Ct. 1948). But cf. Hogan v. Williams, 185 Misc. 338, 55 N.Y.S.2d 904 (Sup. Ct.), aff'd, 270 App. Div. 789, 59 N.Y.S.2d 331 (3d Dep't 1945) (union, not its members, has cause of action for recovery of property belonging to union; court, however, suggested members could have brought a class action). If the employees can prevent such an unathorized diversion, they should be able to restrain the trustees' attempt to release the employer from his obligation or, as here, to compel the trustee to enforce the employer's promise.

36. Even if the member shows that he has exhausted internal remedies, courts may in addition require the member to allege injury to a "property" right before entertaining his suit. Comment, 65 Y ALE L.J. 369, 387-88 (1956). Although the declaration of trust in Slecp recited that the employees have no "proprietory" interest in the fund, see text at note 13 supra, the expectancy that contributions will be forthcoming might constitute a sufficient property interest. See note 16 supra. "[T] here is a property interest in virtually every association suit if a court wishes to acknowledge it." Comment, 65 YALE L.J. 369, 388 (1956).

37. The employer does not withhold at the source any part of his contribution as he does for wages paid in cash to the employee. I.T. 3738, 1 Cuxr. BuLL. 90 (1945); 141 F. Supp. at 466 . Employees are expressly exempted from paying an income tax on "contributions by the employer to accident or health plans for compensation (through insurance or otherwise) to his employees for personal injuries or sickness." INT. Rev. CoDE of 1954, 
ty taxes. ${ }^{38}$ This rationale is inconclusive, however. Retirement benefits are included in gross income when they are received by the employee ${ }^{39}$ thus, in effect, they are deferred wage payments. And other statutes include within the term "wages" pension plans and other fringe benefits. ${ }^{40}$ More important,

$\S 106$. The exclusion, however, "applies only to the portion of the employer's contribution which is allocable to accident or health benefits." U.S. Treas. Reg. \$ 1-106-1 (1956). As to that portion allocable to pension funds, INT. REv. CoDE of 1954, \& 61 applies:

"§61. Gross income defined

(a) General definition.-... gross income means ... (11) Pensions"

Thus, employer payments to a qualified plan are a trade or business expense of the employer, specifically deductible under INT. REv. CODE of 1954, § 404(a); the employee defers payment of the tax until actual receipt of retirement benefits. Id. $\S 402(a)(1)$. An employee's contribution, on the other hand, is included in his gross income when paid as wages, but no deduction is allowed for his contributions. Assuming the employer has a fixed amount to divide up between wages and fringe benefits, his election to increase the wage and eliminate the contribution thus results in a higher tax for the employee. See, generally, Griswold, The Tax Treatment of Employees' Contributions to Pension Plans, 57 HaRv. L. Rev. 247 (1943).

38. INT. Rev. CoDE of 1954, § 3121 provides:

“(a) Wages.-For purposes of this chapter, the term 'wages' means all remuneration for employment, including the cash value of all remuneration paid in any medium other than cash; except that such term shall not include-

(2) the amount of any payment (including the amount paid by an employer for insurance or annuities, or into a fund, to provide for any such payment) made to. or on behalf of, an employee or any of his dependents under a plan or system established by an employer... on account of-

(A) retirement, or

(B) sickness or accident disability, or

(C) medical or hospitalization expenses in connection with sickness or accident disability, or

(D) death;

. . . ."

The term "wages" is interpreted more broadly under the Social Security Act than it is under the income tax. See Pacific Am. Fisheries v. United States, 138 F.2d 464 (9th Cir. 1943) (value of board and lodging taxable for social security purposes even though such remuneration did not give rise to taxable income).

39. Int. Rev. Cone of 1954, $\$ \S 61$ (a) (11), 402 (a) (1) ; Hooker v. Hoey, 27 F. Supp. 489, 490 (S.D.N.Y. 1939) ("The regulations of the Treasury Department from 1918 down to date have declared 'pensions or retiring allowances' to be taxable income."). But see INT. REv. CODE of 1954, $\$ 151$ (c)(1) (permits additional exemption of $\$ 600$ to a taxpayer over 65 ); id. $\$ 37$ (creating a new credit for "retirement income").

40. Sections $8(5)$ and $9($ a) of the National Labor Relations Act, 49 STAT. 449 (1935), as amended, 29 U.S.C. $\$ \S 151-68$ (1952), require an employer to bargain collectively "in respect to rates of pay, wages, hours of employment, or other conditions of employment. ..." In Inland Steel Co. v. NLRB, 170 F.2d 247 (7th Cir. 1948), cert. denied, 336 U.S. 960 (1949), the court, finding that either "wages" or "other conditions of employment" would be broad enough to include a pension plan, upheld the Board's order that the company cease and desist from refusing to bargain collectively on such a plan. See also Cross \& Co. v. NLRB, 174 F.2d 875 (1st Cir. 1949) ("wages" as used in \$ 9(a) embraces group insurance program). Accord, Sherman v. Achterman, 36 L.R.R.M. 2442 
since each separate statute has its own policies and goals, ${ }^{41}$ sounder analysis would limit the inquiry to the meaning of "wages" as it appears in the Bankruptcy Act and to the purposes underlying the wage priority. Bankruptcy courts are almost unanimous in interpreting the term for the benefit of the wage earner. ${ }^{42}$ And cases denying the wage priority for other reasons recognize that "wages" should be interpreted liberally."3 It may of course be true that priorities generally must be strictly construed to avoid obstructing the aim of the Bankruptcy Act to provide equal treatment to creditors. The wage priority, however, has heretofore been strictly construed by jealously limiting its protection to those classes of employees enumerated in the act, not by paring down the protection given to a recognized class of employees. ${ }^{44}$

(Cal. Sup. Ct. 1955), where trustees of a health and welfare fund were allowed to maintain an action against a surety on a bond required by California statute to protect against defaults by public works contractors in payments "for any work or labor thereon of any kind. . . ." Although the trust agreement recited that such payments were not "wages," the court found it unnecessary to decide that the contributions were "wages," but held they were "payments for labor."

The term "wages" has been held to include many other fringe benefits. See, e.g., Glandzis v. Callinicos, 140 F.2d 111 (2d Cir. 1944) (special war bonus constitutes "wages" within $\S \S 3,4$ of the Seamen's Act).

41. See note 38 supra. The Sleep argument that employer contributions are not "wages" for $\$ 64 a(2)$ purposes because they are not for withholding purposes must fall on one of two grounds. If Sleep is right to assume that Congress in enacting both statutes entertained the same notion of what "wages" means, then the opinion must cope with “. . a rule of interpretation to which all assent, that the exception of a particular thing from general words, proves that, in the opinion of the law giver, the thing excepted would be within the general clause, had the exception not been made. ..."

Chief Justice Marshall in Brown v. Maryland, 25 U.S. (12 Wheat.) 419, 438 (1827). The contention that the Sleep court had no authority for reading into the Bankruptcy Act exceptions which are explicit in other statutes appears in Brief for Appellants, pp. 1819, In re Sleep Products, Inc., Bankruptcy No. 89554, $2 \mathrm{~d}$ Cir.

It is, however, more probable that Congress does not have a single notion of "wages" in enacting each statute in which the term appears. Thus, the advisability of interpreting a term in one statute as it appears in others without considering the extent to which the respective policies are similar becomes questionable.

42. Manly v. Hood, 37 F.2d 212, 214 (4th Cir. 1930) ("It is well-settled that provisions of the Bankruptcy Act giving priority to claims for wages due employees are to be liberally construed."); In re Dexter, 158 Fed. 788 (1st Cir. 1907) (“. . . 'wages' must be construed in its broader and more general sense as meaning compensation for services rendered. . . ."); In rc Gurewitz, 121 Fed. 982 (2d Cir. 1903) ("wages" means agreed compensation, however paid); cf. NLRB v. Killoren, 122 F.2d 609 (8th Cir.), cert. denicd, 314 U.S. 696 (1941) (back pay award entitled to priority as constructively earned). Pint sce Strom v. Peikes, 123 F.2d 1003 (2d Cir. 1941) (liberal construction for benefit of wage earner does not justify computation of three month period from date of general assignment rather than from date of filing bankruptcy petition).

43. Matter of Brassel, 135 F. Supp. 827, 829 (N.D.N.Y. 1955), see note 16 supra; Strom v. Peikes, supra note 42.

44. "Where priorities under $\$ 64$ are in issue, a strict construction must be placed thereon and the burden falls upon those asserting a priority to establish that they are 
Finally, in refusing to treat employer contributions as "wages," the Sleep court ignored the historical and practical reasons which have led to widespread adoption of welfare plans. Employer contributions first became prevalent during wartime inflationary periods when the federal government froze wages and salaries. ${ }^{45}$ Even after direct wage increases again became legal, labor representatives continued to press for employer contributions to welfare funds. They recognized that these contributions had proved as appealing to many employees as direct wage increases. Furthermore, welfare plans enhanced the union's bargaining position and, by giving unions alternative goals, added to their flexibility in negotiating for increased remuneration. Unions and employees consequently seek, and think of, employer contributions as the equivalent of wages paid in ready cash.

From the standpoint of legislative intent, however, the Sleep opinion may appear to be on solid ground. The wage priority was originally intended to afford laborers and those in a menial capacity a protective cushion to mitigate the hardship caused by sudden unemployment. ${ }^{46}$ To the extent that employees might be able to benefit from the accident and sickness provisions of the plan, ${ }^{47}$ granting a wage priority would subserve the purpose of the Bankruptcy Act. But, as Sleep points out, ${ }^{48}$ the purpose of the act is hardly advanced by protecting deferred wage payments in the form of retirement benefits. Especially is this the case where the employee has no present right to receive any part of the welfare fund in cash.

The courts, however, should ascribe a broader purpose to the wage priority. By invoking appropriate theories when construing collective bargaining contracts, courts can readily grant wage priorities to employer contributions, and there is ample evidence that this result would not disturb the pattern of priorities prescribed by Congress. Since the inception of unemployment compensation, ${ }^{49}$ the

within the intended class." 3 Colimer, Bankruptcy $\S 64.02$, at 2058 (14th ed., Moore \& Ogleby 1941). Both the author and the Sleep court relied upon cases which held that particular employees are not "workmen, servants, or clerks" within the purview of $\$ 64 a(2)$. In re Paradise-Catering Corp., 36 F. Supp. 974 (S.D.N.Y. 1941) (actor) ; In re Estey, 6 F. Supp. 570 (S.D.N.Y. 1934) (teacher). These decisions may be attributed, however, to a judicial unwillingness to broaden the classes of employees entitled to the wage priority, lest the more needy wage earner's recovery be diluted. See $I n$ re Pacific Oil \& Meal Co., 24 F. Supp. 767 (S.D. Cal. 1938). But cf. In re Witt Dairy Co., 48 F. Supp. 964 (N.D. Cal. 1942) (strictly interpreting the term "costs of administration" in $\$ 64 a(1)$ ); Goldic v. Cox, 130 F.2d 690 (8th Cir. 1942) (same).

45. See Dearing, op. cit. supra note 1, at 35-38; $2 \mathrm{CCH}$ LAB. L. Rer. If 4830 , at 5144 (1955). Also stimulating the growth of union welfare plans is the tax advantage to the employees of this type of compensation. Dearing, op. cit. supra note 1, at 35-38.

46. Blessing v. Blanchard, 223 Fed. 35 (9th Cir. 1915) ; In re Estey, 6 F. Supp. 570 (S.D.N.Y. 1934) ; In re Lawsam Elec. Co., 300 Fed. 736 (S.D.N.Y. 1924).

47. No provision in the bargaining or trust agreements prevents the trustees from continuing to expend monies already in the fund during the employer's bankruptcy.

48. 141 F. Supp. at 467.

49. See Federal Social Security Act, 49 STAT. 626-27 (1935), 42 U.S.C. \$ 501-03 (1952) (authorizing the appropriation of Treasury monies to assist the states in administration of their own unemployment compensation laws). 
wage priority's original function-ameliorating the financial shock of unemployment-has been largely pre-empted. Yet Congress, in numerous amendments to the Bankruptcy Act, has failed to limit the wage priority correspondingly. ${ }^{50}$ This reluctance to change section $64 a(2)$ suggests that Congress preferred to expand the purpose of the wage priority. And this inference is strengthened by clear expressions in other statutes of congressional desire to foster pension plans and congressional concern over the insecurity of many welfare funds. ${ }^{51}$ Both these purposes would be served by including unpaid employer contributions within the wage priority.

50. Since the major revision of the Bankruptcy Act in 1938, (Chandler Act, 52 Star. 840 (1938), 11 U.S.C. $\$ 1$ (1952)), the act has been amended twenty-seven times through 1952. Of these twenty-seven changes, three dealt specifically with $\$ 64$. Bankruptcy Act of 1898 (1952 Collier pamphlet ed.) 1, 107-11.

51. Section 302 of the Taft-Hartley Act, 61 Srar. 157-58, 29 U.S.C. $\S 186$ (1952), makes it unlawful for an employer and a union to establish a welfare fund unless there is joint administration of the fund, there is provision for annual audit the results of which are available to interested persons, and payments for pensions and annuities are made to a separate trust the funds of which can be used for no other purpose.

Similarly, the Internal Revenue Code offers some assurance of permanency to a pension plan. To meet Bureau of Internal Revenue qualifications, pension trusts must be "permanent." This requirement of permanency does not prevent an employer and the union from revoking the plan at will. But if they revoke "within a few years" following the plan's establishment for any reason other than "business necessity" the employer may be taxed on the contributions previously deducted as business expenses. See U.S. Treas. Reg. $\$ 1.401-1$ (h) (2) (1956). Comment, 59 Y ALE L.J. 678, 709 (1950). See also INr. REv. CODE of 1954, \& 401 (a) (2) (corpus or income of qualified trust must be "used for ... exclusive benefit of his employees or their beneficiaries. ..."). Nor can the employer discriminate in favor of high salaried employees in awarding benefits from the trust. Id. $\$ 401(\mathrm{a})(4)$. 